日作紀（Japan. Jour. Crop Sci.）55(3)：306-313（1986)

\title{
水稲における，冠根の出現しなかった要素数と 登熟期の莀水分吸収カとの関係
}

\author{
川島長治 \\ (秋田県立農業短期大学) \\ 昭和 60 年 7 月 31 日受理
}

前報18)において，水稲における冠根の出現した 要素数, あるいは冠根の出現しなかった要素数と地 上部の形質との関係について検討し，登熟期の地上 部の形質は必ずしも冠根の出現した要素数によって 影響を受けないが，冠根の出現しなかった要素数が 少ない場合に良好となることを明らかにした，本報 ではそれらの要素数と登熟期に打ける盖水分吸収力 との関係，とくに冠根の出現しなかった要素数との 関係について検討した結果を報告する。

\section{材 料と方 法}

つぎの 3 つの実験を行なった。

\section{GA 処理実験}

生育段階の異なる 3 つの時期に，第 1 図に示すと おりのジベレリン（以下“GA”という）処理を行 なって伸長節間数を異ならせ，冠根の出現しない要 素数の異なる水稲（それぞれ“1GA 区”，“2GA 区”、“3GA 区”という）をつくって窒素の吸収力, および能動的給水力を示すとされる出液量6,24) を比 較した。

供試材料の育成はつぎの上うに行なった。供試品 種はトヨニシキで, 秋田県農試沖積土壤をつめた 1/2,000a ワグナーポット（以下“ポット”とい うにに 1 ポッ卜当たり 3 株， 1 株 4 本植えとして栽 培した。施肥は，生育期間の違いを考慮して 1GA 区には $10 \mathrm{~g} /$ ポット，2，3GA 区には $8 \mathrm{~g} /$ ポット （化成肥料 13-17-12 で与えた）を基肥としたほか, 材料育成中の施肥量の不足が登熟期の窒素吸収力に 影響をおよぼすことのないように，第1困に示した 時期に硫安 $5 \mathrm{~g} /$ ポット老追肥した．9月 7 日までは 戸外で栽培したが, 1GA 区に比較して出穂期が遅 かった2GA 区や3GA 区（第1図参照）でもでき るだけ 1GA 区と似た高温を与えて根腐れ等の発生 に差が生じないようにするため，9月８日以降はが ラス室内で栽培した。なお各区の伸長節間数は冠根 の出現しなかった要素数（第 1 表）にほぼ等しかっ たが，1GA 区と2GA 区では最上位の 4 5 節間を 除き伸長節間から分けつが出現した。分けつに 3〜4 枚目の葉が抽出する頃になると分けつを包む 葉鞘に縦裂ができたので，その裂け目を利用して分 けつの基部を切断し，除去した。

処理に用いた GA は農薬として市販されている もの（協和酸酵工業製）で，葉面が需れる程度に噴

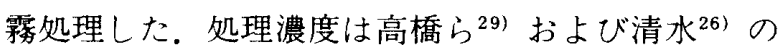

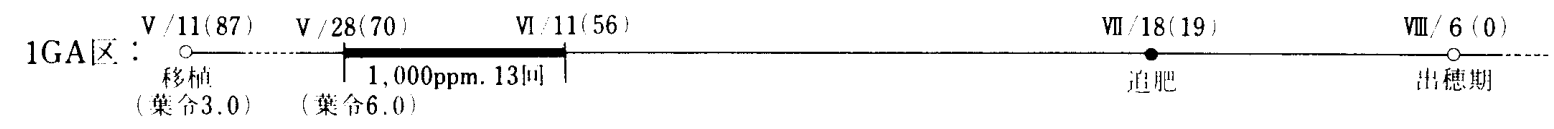

2GAIX:
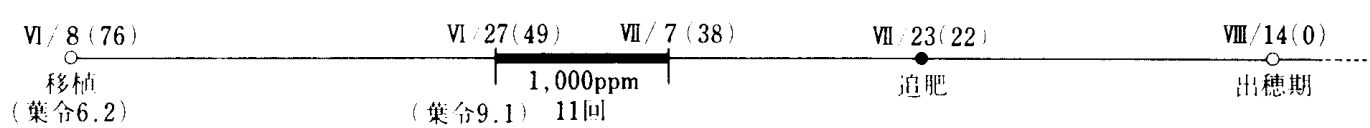

$3 G A \ltimes:$

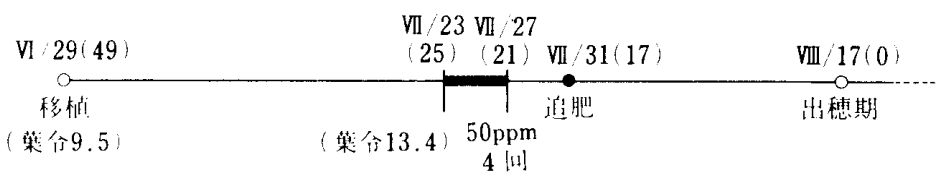

第 1 図 GA 処理実験における処理の大要.

注）3つの区の冠根の出現する要素数をできるだけ同じくして比較を容易にするため，異なった萧 令で移植した。 は GA の処理期間を示し，線の上方には暦日（1984 年）および出 穂期前日数 $[($ ( ) 内 $]$ を示した. 
報告を参考に，節間伸長を引き起こすのに十分であ る一方奇形を生じさせないように留意した。

窒素吸収力は, 出穂期扩よび出穂期後 15,22 , 29 日目の 4 時期に化成肥料 13-17-12:8 g/ポット を追肥し（以下“追肥区”という），はじめの 3 回 については 7 日後, 最後の回は 11 日後に窒素の含 有率（ケルダール法によって測定した）およげ含有 量を求め，追肥を行なわなかった区（以下“無追肥 区”という）の值との差によって比較した。各時期 の測定に用いた材料は 2 ポットに生育した 6 株で, その中から無作為に選抜した 5 本の茥を窒素分析用 に供するとともに，全荎の乾物重を測定した。測定 は穂，荎（葉鞘を含む），葉，枯死部に区分して行 なった。

出液量の測定は平沢らの方法6)により, 出穂期, 出穂期後 $7,15,22,29,40$ 日目の早期に, 前述の 無追肥区について行なった。その場合 $25^{\circ} \mathrm{C}$ 前後に 調節した測定室に前夜から搬入しておいた 2 ポッ ト・6株の中から，6本（1GA 区と2GA 区の出穂 期および $1 \mathrm{GA}$ 区の出穂期後 7 日目）または 10 本 （その他）の茎を無作為に選抜し，最下位伸長節間 (その長さは 1GA区: $4.1 \mathrm{~cm}, 2 \mathrm{GA}$ 区: 15.2 $\mathrm{cm}, 3 \mathrm{GA}$ 区： $13.3 \mathrm{~cm}$ であった）からの出液量を 測定した。

\section{2. 培土処理実験}

培土処理（以下“培土区”という）によって無処 理の水稲（以下“対照区”という）よりも位の要 素（いいかえれば通常は冠根の出現しない，下位の 伸長節間）まで冠根を出現させ，冠根の出現しない 要素数の少ない水稲をつくって出液量を比較した。

本実験は前報18)の培土処理実験と同一であるの で処理法等の詳細は前報を参照されたいが, 概要は つぎのとおりであった。対照区のポットには最初か ら $25 \mathrm{~cm}$ の高さ（ポットの底からの高さ）まで土 壤をつめて栽培したが, 培土区では最初 $15 \mathrm{~cm} の$ 高さまで土壤をつめて栽培した後，8月 13 日，葉 令 16.7 の時（主程葉数は 19.5 ）に厚さ $10 \mathrm{~cm}$ の培 土処理を行なった。

出液量は平沢らの方法6)により，対照区，培土区 のいずれも 2 ポットに生育した 4 株から無作為に選 抜した 5 本の荎の上位 3 葉（葉身を，基部から 3 $\mathrm{cm}$ の部位で切断した）について測定した。測定日 は出穂期と出穂期後 9 日目の 2 回であったが，どち らも室温下で測定を行なったので, 出穂期後 9 日目 にはポットの土壤温度は $19^{\circ} \mathrm{C}$ と低かった。

\section{3. トヨニシキとイシカリの比較実験}

前報14,15,16,17) の結果から, 冠根の出現する要素数 掞よび冠根の出現しない要素数に差のあることが明 らかな品種の1例としてトヨニシキとイシカリを選 び（それぞれ東北地方と北海道の代表的な品種。い ずれの要素数ともトヨニシキの方が多い), 窒素吸 収力と出液量を比較した。

供試材料の育成法はつぎのとおりであった。秋田 県農試神積士壤をつめたポットに，トヨニシキは 1982 年 5 月 28 日に主秙第 6 葉が，イシカリは同年 6 月 11 日に主秙第 5 葉がそれぞれ抽出開始直後の 苗を移植した。いずれも 1 ポット当たり 3 株， 1 株 1 本植えとした。生育期間や最終的な生育程度は卜 ヨニシキの方が大となるから，ポット当たりの基肥 量をトヨニシキは化成肥料 13-17-12:7.7 g, イシ カリは同：5.8g とした。

これらについて, 出穂期後 15，22，29日目の 3

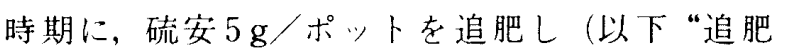
区”という), 最初の 2 回については 7 日後, 最後 の回は 11 日後に窒素の含有率および含有量を測定 し，追肥を行なわなかった区（以下“無追肥区”と いう）との差を求めて窒素吸収力を比較した。各時 期の測定に用いた材料は 2 ポットに生育した 4 株 で，GA 処理実験と同様に選抜・区分して測定した。

一方無追肥区について, 出穂期後 15 日目ほか上 述の 3 回の時期に出液量を比較した。その場合 2 ポ ット・4 株から 5 本の基を無作為に選抜し, 各荎に ついている生葉すべて（葉身がわずかでも生きてい る葉を含む）について測定した。最初の 2 回は気温 が高かったので室温下で測定したが, 最後の回は $25^{\circ} \mathrm{C}$ に調節した測定室で測定した。

なお，川田ら ${ }^{12)} の$ “要素”という見解にしたが つて検討をすすめる，そのため冠根や分けつが“節 間”から出現するという表現を用いることがある. “冠根の出現”に関する定義については前報18) を参 照されたい。

第 1 表 GA処理実験における冠根の出現 しなかった要素数.

\begin{tabular}{ll}
\hline & $\begin{array}{c}\text { 冠根の出現しなか } \\
\text { つた要素数 }\end{array}$ \\
\hline 1 GA区 & $9.8 \pm 0.4$ \\
2 GA区 & $8.0 \pm 0.7$ \\
3 GA区 & $5.3 \pm 0.6$ \\
\hline
\end{tabular}




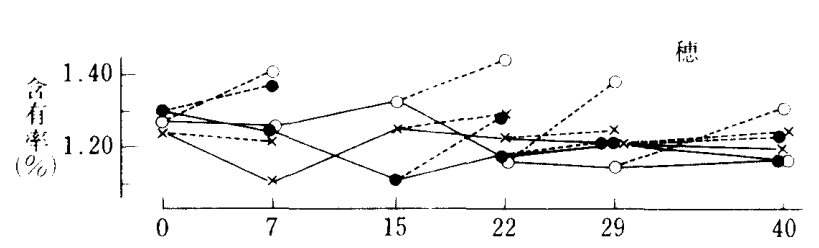

\section{結果}

\section{GA 処理実験}

冠根の出現しなかった要素数の違いは第 1 表のと おりであった。

1）窒素の含有率および含有量を測定した結果は

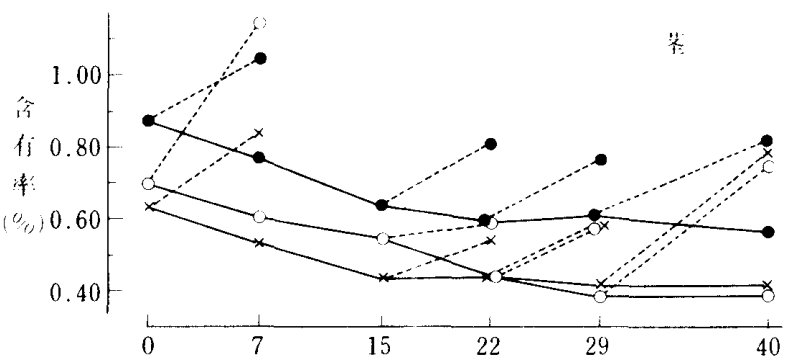

つぎと扪りであった。

第 2 表 $G A$ 処理実験における，追肥による窒素含有 率の上無程度*

\begin{tabular}{|c|c|c|c|c|c|}
\hline & \multirow{2}{*}{ 器官 } & \multicolumn{4}{|c|}{ 出穂期後日数 } \\
\hline & & 7 & 22 & 29 & 40 \\
\hline \multirow{3}{*}{ 1 GA区 } & 穂 & $0.12 \%$ & $0.10 \%$ & $0.00 \%$ & $0.06 \%$ \\
\hline & 茥 & 0.27 & 0.21 & 0.15 & 0.25 \\
\hline & 藮 & 0.40 & 0.33 & 0.38 & 0.55 \\
\hline \multirow{3}{*}{2 GA区 } & 穂 & 0.11 & 0.07 & -0.04 & -0.05 \\
\hline & 荎 & 0.30 & 0.10 & 0.17 & 0.38 \\
\hline & 葉 & 0.65 & 0.51 & 0.39 & 0.77 \\
\hline \multirow{3}{*}{$3 \mathrm{GA} 区$} & 穂 & 0.16 & 0.28 & 0.24 & 0.15 \\
\hline & 葓 & 0.53 & 0.15 & 0.18 & 0.36 \\
\hline & 葉 & 0.60 & 0.55 & 0.61 & 1.04 \\
\hline
\end{tabular}

*：追肥区と無追肥区の䓨素含有率の差

第 3 表 $\mathrm{GA}$ 処理実験における，追肥による窒素含有 率の上昇程度の区間差

\begin{tabular}{|c|c|c|c|c|c|}
\hline \multirow{2}{*}{ 区，間 } & \multirow{2}{*}{ 器角 } & \multicolumn{4}{|c|}{ 出穗期後日数 } \\
\hline & & 7 & 22 & 29 & 40 \\
\hline \multirow{3}{*}{$\begin{array}{l}2 \text { GA区 -- } \\
1 \text { GA区 }\end{array}$} & 穂 & $-0.01 \%$ & $-0.03 \%$ & $-0.04 \%$ & $-0.11 \%$ \\
\hline & 萃 & 0.03 & -0.11 & 0.02 & 0.13 \\
\hline & 葉 & 0.25 & 0.18 & 0.01 & 0.22 \\
\hline \multirow{3}{*}{$\begin{array}{l}3 \mathrm{GA} 区- \\
1 \mathrm{GA} 区\end{array}$} & 穂 & 0.04 & 0.18 & 0.24 & 0.09 \\
\hline & 荎 & 0.26 & -0.06 & 0.03 & 0.11 \\
\hline & 葉 & 0.20 & 0.22 & 0.23 & 0.49 \\
\hline \multirow{3}{*}{$\begin{array}{l}3 \text { GA区 - } \\
2 \text { GA区 }\end{array}$} & 穗 & 0.05 & 0.21 & 0.28 & 0.20 \\
\hline & 萎 & 0.23 & 0.05 & 0.01 & -0.02 \\
\hline & 葉 & -0.05 & 0.04 & 0.22 & 0.27 \\
\hline
\end{tabular}

区，○一○：3GA区，破線は追肥区における上昇程度 を示す。

第 4 表 GA処理実験における, 地,上部乾物重 $1 \mathrm{~g}$ 当たり窒素含有量の推移，および追肥による增加量**.

\begin{tabular}{|c|c|c|c|c|c|c|c|c|c|c|}
\hline & & \multicolumn{3}{|c|}{ 出 } & 期 & 後 & \multicolumn{2}{|c|}{ 数 } & & \\
\hline & & 0 & 7 & 15 & \multicolumn{2}{|c|}{22} & \multicolumn{2}{|c|}{29} & \multicolumn{2}{|c|}{40} \\
\hline & & $\begin{array}{l}\text { 無追 } \\
\text { 肥区 }\end{array}$ & $\begin{array}{l}\text { 無追 追肥区 } \\
\text { 肥区 }\end{array}$ & $\begin{array}{l}\text { 無追 } \\
\text { 肥区 }\end{array}$ & $\begin{array}{l}\text { 無追 } \\
\text { 肥区 }\end{array}$ & 追肥区 & $\begin{array}{l}\text { 無追 } \\
\text { 肥区 }\end{array}$ & 追肥区 & $\begin{array}{l}\text { 無追 } \\
\text { 肥区 }\end{array}$ & 追肥区 \\
\hline \multirow{2}{*}{1 GA区 } & 含有量* & 12.95 & $11.50 \quad 14.38$ & 9.35 & 8.51 & 10.49 & 8.32 & 9.76 & 7.64 & 9.86 \\
\hline & 増加量 & \multicolumn{2}{|r|}{2.88} & & \multicolumn{2}{|c|}{1.98} & \multicolumn{2}{|c|}{1.44} & \multicolumn{2}{|c|}{2.22} \\
\hline \multirow{2}{*}{2 GA区 } & 含有量 & 10.84 & $8.54 \quad 12.40$ & 7.52 & 7.43 & 9.06 & 7.07 & 8.67 & 7.25 & 10.06 \\
\hline & 增加量 & \multicolumn{3}{|c|}{3.86} & \multicolumn{2}{|c|}{1.63} & \multicolumn{2}{|c|}{1.60} & \multicolumn{2}{|c|}{2.81} \\
\hline \multirow{2}{*}{3 GA区 } & 含有量 & 12.19 & $10.47 \quad 15.63$ & 9.49 & 8.18 & 10.54 & 8.19 & 10.52 & 8.29 & 11.31 \\
\hline & 增加量 & \multicolumn{3}{|c|}{5.16} & \multicolumn{2}{|c|}{2.36} & \multicolumn{2}{|c|}{2.33} & \multicolumn{2}{|c|}{3.02} \\
\hline
\end{tabular}

* : mg/地上部乾物重 $1 \mathrm{~g},{ }^{* *}$ : 追肥に上る窒素含有量の増加量. 
窒素含有率（第 2 図，第 2,3 表）：穂についてみ ると，無追肥区においては3つの区の間に明瞭な差 のない推移を示したが，追肥による上界は1GA 区 や 2GA 区より 3GA 区で大きい傾问があつた。茥 では，無追肥区においては 1GA 区の含有率が他の 2 区より終始高かったが，追肥による上昇には3つ の区の間にほとんど差はなかった。葉では, 無追肥 区においては出穂期後 15 日目まで2GA 区の含有 率が低かったが, 追肥により 1GA 区、,2GA 区， 3GA 区の順で大きく上昇する傾向が認められた。

地上部乾物重 $1 \mathrm{~g}$ 当たり窒素含有量（第 4,5 表）：測定日ごとの乾物重の变動が比較的大きく, 常法のように测定日間の個体当たり含有量の差によ って吸收量を求好るこは困難であった。そこで地 上部乾物重 $1 \mathrm{~g}$ 当たりの窒素含有量壮1により吸収 お在比較することにする。

各区の無追肥区における含有量（第 4 表）は出穂 期後日数が経過するにつれて低下した。3つの区の 間では，2GA 区の含有量が 1GA 区や3GA区より 少なかった。

追肥による含有量の增加程度をみると（第 4,5 表), 出穂期後 22 日目あるいは29日目にみられる ように，1GA区より2GA区のカが少ないか差が大 きくない場合毛あったが，概して 1GA 区より2GA 区の方が多く，またこれら2区より3GA 区の方が 多かった。

2) 出液量を測定した結果 (第3汹)，出穂期後 7 日目の 2GA 区を除き, 終始, 1GA区, 2GA 区, 3GA 区の順で多い傾向が認められた。

なお，以上の結果の考察に必要と思われる $1 \cdot 2 の$ 点を検討した結果はつぎのとおりであった。

i. GA 処理をすると, 茥葉の著しい伸長生長 が起り（本来験に扩いても同様であった） $\mathrm{T} / \mathrm{R}$ ratio が変化することが知られている22.30) ので出穂 期にこのことを検討した。 その結果 (第 6 表)，3 つの区の差は少なかった。

ii. 前述のとおり, 出液量は1GA区，2GA区， 3GA 区の順で多い傾向を示したが、これは茎の太 さと同様の傾向であったので両者に相関関係のある ことも考えられた。

$\mathrm{GA}$ 処理実験の水稻を用いた直接の検討は行なわ なかったが, トヨニシキとイシカリの茎の直径

注 1)計算法からいって, “全器官を込みにした地上部 全体に対する窒素含有率”と同義的な側面を有す 万.
(4〜 $5 \mathrm{~cm}$ 以上に伸長した節間のうちで最下位の節 間の中央部の太さ）はそれぞれ $3.5 \mathrm{~mm} と 2.7 \mathrm{~mm}$ で, 出液量の多いイシ力り（詳細は後述する）の方

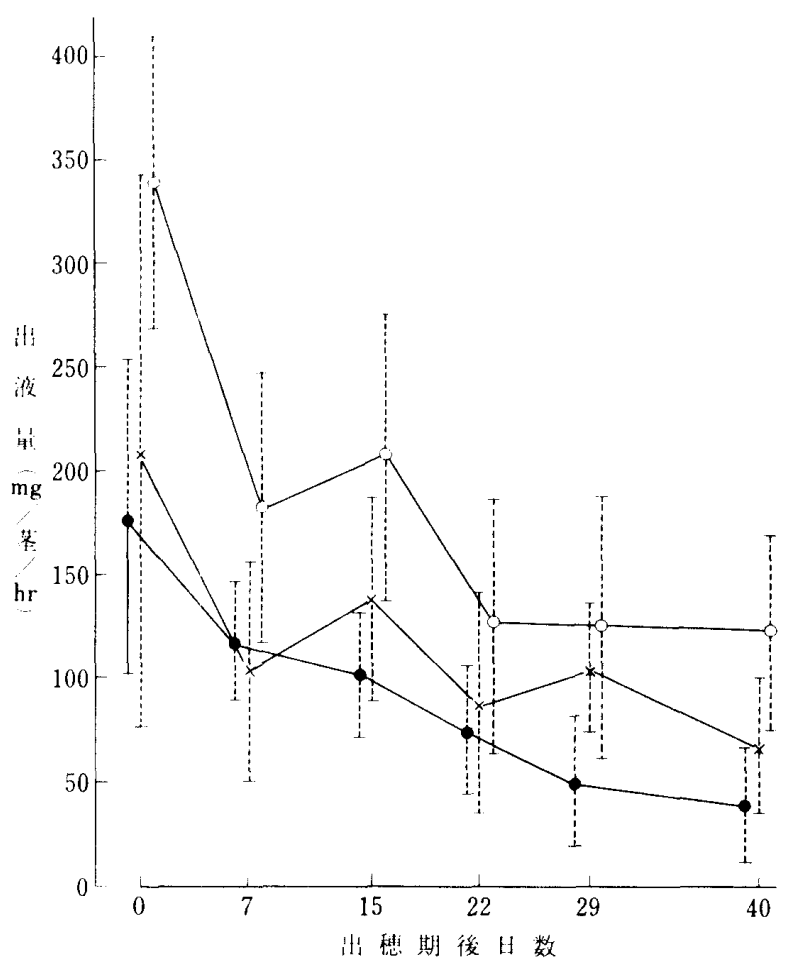

第 3 困 GA 処理実験における出液量の推移. ○一○: IGA 区, ×-x:2GA 区, ○-○:3GA 区. 縦の破線は標準偏差の幅を示す。

第 5 表 GA処理奏験における，追肥による窒素含有 量*の增加量の区間差.

\begin{tabular}{|c|c|c|c|c|}
\hline \multirow{2}{*}{$\vec{x}$} & \multicolumn{4}{|c|}{ 出穂 期 後 日 数 } \\
\hline & 7 & 22 & 29 & 40 \\
\hline 2 GA区 - 1 GA区 & 0.98 & -0.35 & 0.16 & 0.59 \\
\hline $3 G A 区-1 G A 区$ & 2.28 & 0.38 & 0.89 & 0.80 \\
\hline 3 GA区 -2 GA区 & 1.30 & 0.73 & 0.73 & 0.21 \\
\hline
\end{tabular}

第 6 表 GA処理実鈤における T/R ratio.

\begin{tabular}{|c|c|c|c|}
\hline & 地上部重 & 根 重 & $\mathrm{T} / \mathrm{R}$ ratio \\
\hline $1 \mathrm{GA} \overline{\bar{X}}$ & $31.9 \mathrm{~g}$ & $5.2 \mathrm{~g}$ & 6.1 \\
\hline 2 GA区 & 67.8 & 9.3 & 7.3 \\
\hline 3 GA区 & 48.1 & 6.6 & 7.3 \\
\hline
\end{tabular}

第 7 表 培土処理実験における出液量*の推移.

\begin{tabular}{|c|c|c|c|c|}
\hline & & 出 穂 & 期 後 & 日 \\
\hline & & \multicolumn{2}{|l|}{0} & 9 \\
\hline & 照 区 & 51 & & 10 \\
\hline & 土 区 & 95 & & 19 \\
\hline
\end{tabular}

*: $\mathrm{mg} /$ 上位 3 葉 $/ \mathrm{hr}$ 

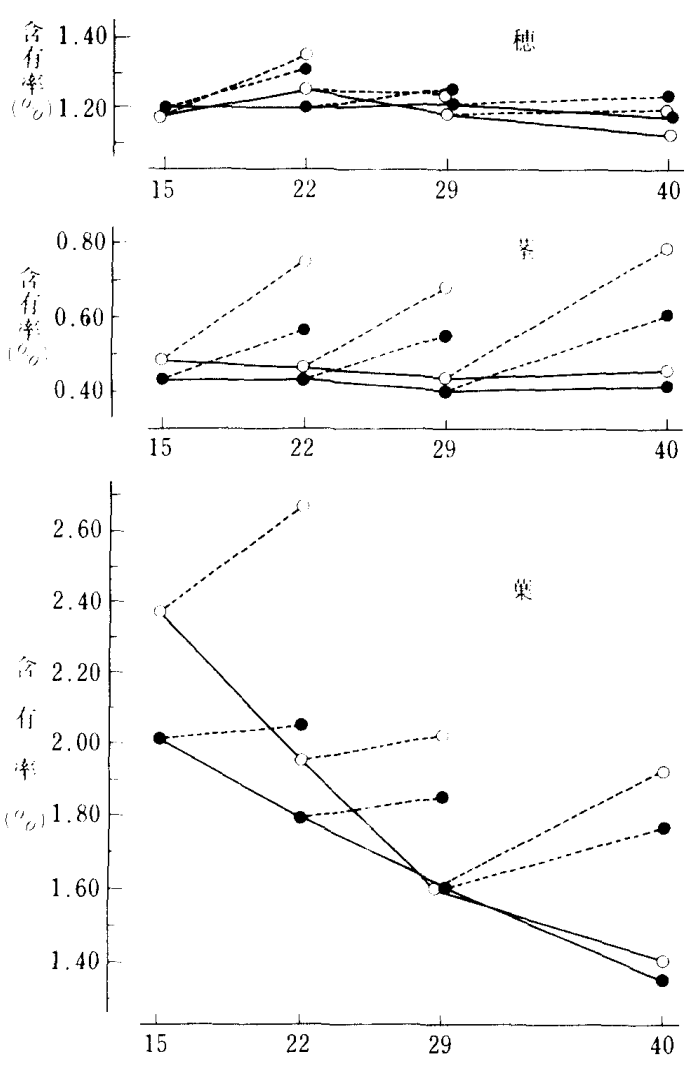

第 4 図トヨニシキとイシカリの比較実験に おける, 窒素含有率の推移および追 肥による上昇。

○一トヨニシキ，○一○：イシカリ。

横軸は出穂期後日数. 実線は無追肥区の推移を示し, 破線は追肥区における上昇程度を示寸。

が細かった。

\section{2. 培土処理実験}

培土処理の結果，培土区の伸長節間数は 7 個（対 照区では 6 個）となり，第5７要素（この場合， 穂首節直下の節間を含む要素を第 1 要素として, 向 基的に数えた）の節間長は对照区の1.4〜 1.8 倍と なった。しかし 5，6要素上位根の出現は培士区の みに認女られ (前報 ${ }^{18)}$ の第 8 表参照), 上位要素根 の出現が促進された。

出液量をみると、いずれの測定日とも培土区にお いては対照区の約 2 倍の值を示した(第 7 表).

\section{3. トヨニシキとイシカリの比較実験}

1) 窒素吸収力

窒素含有率（第 4 四）：穂については，各測定時 期ともに，無追肥区，追肥区のいずれも2つの品種 の間に明瞭な相違は認められなかった。しかし茥や 葉では，追肥によりイシ力りの方が明らかに含有率 が上昇した。すなおち茥については，無追肥区にお いても終始イシカリの方が高い傾向が認力ら机た
第 8 表 トヨニシキとイシカリの比較実験に扔ける窒 素含有量*の推移。

\begin{tabular}{|c|c|c|c|c|c|}
\hline & & \multicolumn{4}{|c|}{ 出穂期 後 日 数 } \\
\hline & & 15 & 22 & 29 & 40 \\
\hline \multirow{2}{*}{ トヨニシキ } & 無追肥区 & 505 & 557 & 546 & 563 \\
\hline & 蜑肥区 & & 662 & 645 & 654 \\
\hline \multirow{2}{*}{ イシ力リ } & 無追肥区 & 368 & 401 & 464 & 443 \\
\hline & 追肥区 & & 536 & 590 & 604 \\
\hline
\end{tabular}

$*: \mathrm{mg} /$ 株

第 9 表 トヨニシキとイシカリの比較赛験に拈ける 追肥窒素の 1 日当たり吸収量*の推移.

\begin{tabular}{lccc}
\hline & \multicolumn{3}{c}{ 出穂期後の期間 } \\
\cline { 2 - 4 } & $15 \sim 22$ & $22 \sim 29$ & $29 \sim 40$ \\
\hline トヨニシキ & 22.4 & 12.8 & 9.0 \\
イシカリ & 24.0 & 27.0 & 13.7 \\
\hline *: $\mathrm{mg} /$ 株 & \multicolumn{3}{c}{}
\end{tabular}

第10表 トヨニシキとイシカリの比較実験における 出液量*の推移.

\begin{tabular}{lrrr}
\hline & \multicolumn{3}{c}{ 出 穂 期 後 日 数 } \\
\cline { 2 - 4 } & 15 & 22 & 29 \\
\hline トヨニシキ & 68 & 35 & 10 \\
イシカリ & 144 & 58 & 19 \\
\hline
\end{tabular}

*: $\mathrm{mg} /$ 上位の生葉/ $\mathrm{hr}$

第11表 トヨニシキとイシカリの比較実験における 1 茎当たり生葉数の推移.

\begin{tabular}{|c|c|c|c|}
\hline & \multicolumn{3}{|c|}{ 出穂期 後日 数 } \\
\hline & 15 & 22 & 29 \\
\hline トヨニシキ & 3.7 枚 & 3.2 枚 & 3.0 枚 \\
\hline イシカリ & 2.7 & 2.4 & 2.1 \\
\hline
\end{tabular}

が，追肥区では一層高くなった。葉では，無追肥区 の含有率は出穫期後 22 日目まではイシ力りの方が 著しく高く，それ以降はトヨニシキとほぼ等しいか 差が少ない様相を示したが，追肥による含有率の上 昇は終始イシカリの方が大であった。

追肥窒素の 1 日当たり吸収量：まず各測定時期に おける株当たり窒素含有量を求め（第 8 表）その 結果から各期間中の 1 日当たり吸収量を求妉（第 9 表)。含有量を求める場合の乾物重は，各測定日 の材料の各荎を生育程度により2群に分け，一方の 3 本の茎の乾物重が他方の 2 本分に相当するものと しで22株当たり菜数を補正した後, 全測定日の平 注 2 ) 予備実験によれば 2 群の乾物重の比率は $100 ： 63$ であった 
均基数に相当する乾物重に補正した。また第 8 表の 無追肥区をみると，トヨニシキについては出穂期後 22 日目以降, イシカリでは出穂期後 29 日目以降の 含有量がほぼ等しい，すなわち無追肥区においては それらの時期までに窒素の吸収はほぼ終了したとも 考之られる，そこで第 9 表の值を求めるにあたっ て, 上述の時期以降についてはそれらの含有量の平 均値をもって無追肥区の窒素含有量とした。

第 9 表によれば，1日当たり吸収量は終始イシカ リの方が多かった。なお GA 処理実験と同様に, 地上部乾物重 $1 \mathrm{~g}$ 当たりの含有量によって比較して ももちろんイシカリの方が多かった。

\section{2) 出液量}

出液量は終始イシカリの方が多く、トヨニシキの 約 2 倍の値を示した (第 10 表). な挹 1 茎当たり生 葉数はイシカリの方が少なかった (第 11 表).

\section{考察}

1. GA 処理実験において，1GA 区と2GA 区の $\mathrm{GA}$ 濃度は著しく高く，3GA 区は 1，2GA 区より 処理時期が出穂期に近かった。しかし処理した GA の稲体内における活性は急速に消失寸ることが知ら

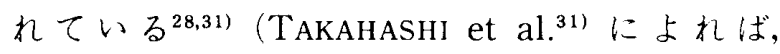
$1,000 \mathrm{ppm}$ の濃度で処理しても2 日後にはほとんど 消失する)。また，養分吸収に挹よぼす GA 処理の 影鏊に関する従来の研究結果4,8,11,22,34)をみても，促 進と抑制のいずれの場合もあって一定の傾向は認め られていないし，3つの区の間の $\mathrm{T} / \mathrm{R}$ ratio の差も 少なかった。これらのことから $\mathrm{GA}$ 处理実験の結 果は GA で処理したことの影響を考慮することな く比較してよいと考之られる。

2. 窒素吸収力の比較に招いて, GA 処理実験に ついては，含有率の上昇では葉を除くと 3 つのの 間の差は必ずしも明瞭ではなかったが, 地上部乾物 重 $1 \mathrm{~g}$ 当たり含有量の増加は 1GA 区, 2GA 区, 3GA 区の順で多い傾向が認められた。

トヨニシキとイシカリの比較実験では追肥による 荎や葉の窒素含有率の上昇, 1 日当たり吸収量とも にイシカリの方が大であった。ただし無追肥区にお いて，トヨニシキでは出穂期後 22 日目までに，イ シカリでは出穂期後 29 日目までに吸収可能な窒素 は吸収しつくされていたとも考之られた。もしてう であれば，この実験によって吸収力の比較を行なう ことは妥当でないかもしれない.しかしトヨニシ キ,イシカリともに明らかに窒素が残っていた時
期，すなわち出穂期後 22 日目の追肥区における茎 葉の含有率はイシカリの方が高かったし，また雨品 種ともに窒素が吸収しつくされたとも考之られる出 穂期後 29 日目から同 40 日目までの茎葉の含有率の 上昇，およびその間の1日当たり吸収量はいずれも イシカリの方が大であったから，登熟期に打ける窒 素吸収力はイシカリの方がやはり大であったと考之 られる。

能動的吸水力を示すとされる出液量は, $\mathrm{GA}$ 処理 実験では1GA 区，2GA 区，3GA 区の順で多く， 培土処理実䮖においては培士区の方が多く, トヨ二 シキよりイジリの方が多かった。その場合, 区間 の差は窒素吸収力よりも明膫であった。

以上加，登熟期に扮ける養水分の吸収力は冠 根の出現しない要素数が少ないほど大きい傾向とな ると考之られる。そしてその傾向は吸水力に扔い て，より顕著である。な拉，トヨニシキよりイシカ リの方が冠根の出現した要素数が少ないことからす ると, 養水分の吸収力は必ずしも冠根の出現した要 素数によ一て左右されないと推察される.

3. 種 ${ }^{1,2)}$ や盖分の種類 $\left.2.3,5,7\right)$ に上って电異なる が, 盖水分の吸収や移動は根の先端に近い部分のみ ならず基部奇りの部分でも起こる あるいはある程度 age のすすんだ根の方がむしろ 盛んであるともいわれる21,32,33,35). しかし1本の根 全体の養水分吸収力はやはり age の進行とともに 低下寸る2,3,5,7,13,23,32,33,35,36). 前報(6) で明らかにした ように，冠根の伸長終了時期はトヨニシキよクイシ カリの方が遅いし，GA 処理実験に扔いては1GA 区，2GA 区，3GA 区の順で冠根の出現しない要素 数が少なく，培士処理実験においては培土処理によ って.上:位要素根の出現が促進されたから，冠根の出 現しない要素数の相違にもとづく冠根の aging の 違いが登熟期における養水分吸収力と密接に関係し ていたと考えられる。そしてまたこのような養水 分吸收力の差異が前報18) の断根处理実験や培土処 理実験にみられたような地上部の形質の相違をもた らしたと思われる。

4. すでに著者は, 冠根の出現する要素数 ${ }^{14,16,17)}$ あるいは冠根の出現しない要素数14,15,16,17) が主秙葉 数によって異なることを明らかにした。そこでこの ことと上述の考察とをあわせて考之ると，主秙葉数 の多い水稲は，冠根の出現しない要素数が多いこと によって登熟期に打ける養水分吸収力が低下しやす いと考えられる。また，そのために地上部の形質も 
不良となりやすいと推察される。ただし主稈葉数の 多い水稲は穂数の確保が容易であったり10)，あるい は，たとえば出穂期における 1 荃当たりの生葉数や 葉面積が多い9,10) という優れた点を有するので，前 述のことは主稈葉数によって異なることの1つの側 面であることはいうまでもない。

謝辞：実験を行なうにあたり東京農工大学教授石原 邦博士にはご助言を，秋田県農試には土壤をいただ いた。また本学土壤肥料学研究室には窒素分析に便 宜を計っていただき，伊藤昭子孃には種々お手伝い いただいた。さらに本学山邦夫教授には論文のご 校閲をいただいた。ここに記して謝意を表します。

\section{摘 要}

水稲における冠根の出現しなかった要素数と登熟 期の養水分吸収力との関係をみるために，GA 処理 実験，培土処理実験，トヨニシキとイシ力リの比較 実験を行なった。

1.いずれの実験においても冠根の出現しなかっ た要素数の少ない区の養水分吸収力，とくに水分吸 収力が優れていた。

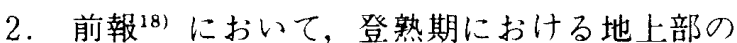
形質は冠根の出現しない要素数が少ないと良好とな ると考えられたが，このことには冠根の出現しない 要素数の相違にもとづく養水分吸収力の差が関係し ていると推察される。

3. 主秙葉数の多い水稲は冠根の出現しない要素 数が多いので，登熟期における養水分吸収力が低下 しやすく，地上部の形質を高く維持する上で不利な 側面を有すると考之られる。

\section{引用文献}

1. CANNing, R.E. and P.J. KRAmeR 1958. Salt absorption and accumulation in various regions of roots. Amer. J. Bot. 45: 378-382.

2. Clarkson, D.T. and J.B. HANSON 1980. The mineral nutrition of higher plants. Ann. Rev. Plant Physiol. 31 : $239-298$.

3. FERGuson, I.B. and D.T. Clarkson 1975. Ion transport and endodermal suberization in the roots of Zea mays. New Phytol. 75: 69-79.

4. 原田二郎 1975. ジベレリン酸処理水稲の登熟に及ば す出穂期空素追肥並びにアミ/酸,核酸処理の影響 (予報)。日作東北支部報 $17: 14-15$ 。

5. HARRISON-MURRAY, R.S. and D.T. CLARKSON 1973. Relationships between structural development and absorption of ions by the root system of
Cucurbita pepo. Planta 114: 1-16.

6. 平沢 正・荒木俊光・松田永…石原 邦 1983. 水 稲葉身基部の出液速度について，日作紀 52：574一 581 .

7. 稲田勝美 1967. 水稲根の生理的特性に関する研究. 一とくに生育段階ならびに根の age の観点におい て一一農技研報告 D16：19-156.

8. 石塚喜明・広瀨 晃・橎 守 1961. 水稲の生育に 及ばす Gibberellin と養分供給との相互関係，特に 水稲增収剂としての可能性の検討（第 4 報）。処理時 期巽にした場合の Gibberellinの水稻生育に対方 る影響。土肥誌 32: 413-418.

9. 一一田中 明 1963. 水稲の栄養生理. 養賢堂, 東京. $268-271$.

10. 柿本 彰 1968. 寒地多収地带における水稲の生育相. 日本作物学食シンポジウム紀事 1:7-11.

11. 勝見允行・加藤次郎 1969. ジバレリンの生理作用. 田村三郎編 ジベレリン。東大出版会，東京。263361 .

12. 川旧信‥郎・山崎耕宇・石原 邦·芝山秀次郎·頼 光 隆 1969. 水稲に打计る根群の形態形成について，と くに生育段階に着目した場合の一例. 日作紀 32: 163 -180 .

13. 一賴 光隆 1968. 水稲冠根における内皮細 胞の分化過程と吸水との関係. 日作紀 37:631--639.

14. 川島長治・伊藤文们 1977. 水稲に㧍ける主䄸葉数と 冠根の出現した要素数との関係. 日作紀 46：343351 .

15. - 1983. 水稲における第 1 苞の止葉化と冠根 の出現しない要素数との関係，日作紀 52:151-157.

16. 一 1983. 水稻における, 主程葉数と冠根の伸 長終了時期との関係，日作紀 54：475--483.

17.—1985. 水稲において, 冠根の出現しない要 素数が主稈葉数によって異なることの要因につい て.日作紀 54:220-225.

18.—1986. 水稲における, 冠根の出現した要素 数あるいは冠根の出現しなかった要素数と登熟期の 地上部の形質との関係. 日作紀 55:229-235.

19. KrAMER, P.J. and H.H. WIEBE 1952. Longitudinal gradients of $\mathrm{P}$ absorption in roots. Plant Physiol. $27: 661-674$

20. 1956. Roots as absorbing organs. Handbuch der Pflanzenphysiologie III : 188--214.

21. 岡島秀夫 1960 . 水稲根群の生理機能に関する研究. 一とくに窒素栄盖を中心にして一。東北大農研巣報 $12: 1-146$.

22. 大西敏夫・版本有彦 1982. 桑樹の盖分吸収におよば すジべレリン処理の影传. 植物の化学調節 $17: 150$ 152.

23. Robards, A.W., S.M. Jakson, D.T. Clarkson and J. SANDERSON 1973. The structure of barley roots in relation to the transport of ions into stele. Protoplasma $77: 291-311$.

24. ラッセル, R.S. 1977. 作物の根系上土壤. 田中典幸訳 1981. 農文協, 東京. 125.

25. SANDERSON, J. 1983. Water uptake by different regions of the barley root. Pathways of radial 
flow in relation to development of the endodermis. J. Exp. Bot. 34 : 240-253.

26. 清水正治 1965 . 水稻の形態形成におよばすジベレリ ン酸の影響. 第 1 報 生育時期別処理の影響. 日作紀 $33: 379-387$.

27. SMITH, R. and I. MAJEED 1981. Longitudinal gradients of transport in corn roots. Amer. J. Bot. 68: $1257-1262$.

28. SugE, H. 1792. Physiology of flowering in rice plants. V. Persistence of applied gibberellin $\mathrm{A}_{3}$ and $A_{7}$ and their effect on the photoperiodic floral induction. Proc. Crop Sci. Soc. Japan 41: 51-56.

29. 高橋 清 - 佐藤 庚・輪田 潔 1972. 水稲節間の伸 長機構に関する研究. 第 4 報 ジベレリン酸の節間伸 長誘起効果. 日作紀 41：449-453.

30. ——・藤野敏明 1972. ジベレリン酸 処理が水稲の生育・收量に及ばす影響. 日作束北支部 報 14: 43-46.

31. TAKAhashi, K., K. Sato and J. Habashita 1973. The effects of gibberellic acid on the growth of rice plant under different temperatures. Tohoku Jour. Agr. Res. 23 : 175--183.

32. TATSUMI, J. and Y. KoNO 1979. Effects of shading on respiration and ammonium uptake of rice roots. - Comparison of activity in roots from different nodes --. Japan. Jour. Crop Sci. 49 : 349 358.

33. - 1980. Nitrogen uptake and transport by the intact root system of rice plants. --Comparison of the activity in roots from different nodes $\cdots$. Japan. Jour. Crop Sci. 49 : 349-358.

34. 山田 登 1971. 作物のケミカルコントロール. 農業 技術協会，東京。115-153。

35. 山川 寛・岸川英利 1955. 暖地における水稲の栽培 時期に関する研究. III. 地下部の発達, 水田土壤の温 度及び酸化還元電位に及ぼす栽培時期の影響. 佐賀 大学農学氣報 $5: 41-96$.

36. 吉田武彦・中村正治 1968 . 水稻根の各部位におけ る ${ }^{86} \mathrm{Rb}$ およU゙ ${ }^{32} \mathrm{P}$ 吸収能の差異について。 土肥誌 39 : $253--257$.

\title{
Relation of the Number of Shoot Units without Crown Roots to Ability of Nutrient and Water Absorption in the Ripening Stage of Rice Plant
}

\author{
Choji Kawashima \\ (Akita Prefectural College of Agriculture, Ohgata-mura, Akita 010-04)
}

\begin{abstract}
Summary
Following the previous paper ${ }^{18)}$ in which the number of shoot units with or without crown roots were studied in relation to the characters of the top of rice plant, several investigations were conducted in order to clarify the relation of the number of shoot units without crown roots to absorption of nitrogen and water in the ripening stage.

Greater absorption of nitrogen and water, especially the latter, occurred in the rice plants which had lesser number of shoot units without crown roots and which were caused by moulding up the lower part of stems or by GA treatment in the later growth stage. Compared with cultivar Toyonishiki, similar situation was found in cultivar Ishikari whose number of shoot units without crown roots was less numerous.

From these results, it is indicated that the number of shoot units without crown roots has intimate relation to absorption of nutrient and water in the ripening stage of rice plant and is considered that cultivar whose number of leaves on the main stem is numerous has disadvantage to keep the activity of top and root in the ripening stage high, because it has more numerous shoot units without crown roots than that having less number of leaves on the main stem.
\end{abstract}

